\title{
ANTI-INFLAMMATORY PROPERTIES OF UNEXPLORED PLANTS - CUSCUTA REFLEXA AND COCCULUS HIRSUTUS - AN EXPERIMENTAL STUDY
}

\author{
ANITA SINGH, VANDANA SINGH, DINESH KUMAR BHARATRAJ* \\ Food and Drug Toxicology Research Centre, National Institute of Nutrition - ICMR, Hyderabad, Telangana, India. \\ Email: nindineshpct@gmail.com
}

Received: 07 April 2021, Revised and Accepted: 15 May 2021

\section{ABSTRACT}

Objective: The study aimed to document the rarely explored plants, namely, Cuscuta reflexa (CRA) and Cocculus hirsutus (CHP) used by the ethnic people of a specific region. The anti-inflammatory (AI) property of kwath of CRA (KCRA), kwath of CHP (KCHP), and their blend (kwath blend [KB]) was also assessed.

Methods: The KCRA and KCHP were prepared following standard Ayurvedic procedures. The AI property was determined by carrageenan-induced paw edema at doses; 250, 125, and $62.5 \mathrm{mg} / \mathrm{kg}$. The KB $(500 \mathrm{mg} / \mathrm{kg})$ was prepared using equal parts of KCRA and KCHP in view of the potential AI property as compared to the individual plants. Ibuprofen (100 mg/kg) was used as the standard AI drug standard drug (SD).

Results: The carrageenan-induced paw inflammation was highest and doubled at $3 \mathrm{~h}$. The oral administration of SD (100 mg/kg) produced a high reduction of edema (78.47\%) at $3 \mathrm{~h}$. Both KCRA and KCHP had reduced edema and were equally potent (EC50; 139.8 and $147.3 \mathrm{mg} / \mathrm{kg}$, respectively) at the early phase. However, the efficacy of KCRA was greater than KCHP at the second phase of inflammation (EC50=313.6 and 2760 mg/kg, respectively). KCRA was efficacious and potent as an AI agent. Unlike SD, KB had effectively inhibited paw edema from the $6^{\text {th }}$ h onward. The AI activity of KB was superior compared to individual plant groups.

Conclusions: The study demonstrated that the traditional formulation - kwath of rarely explored plants, namely, CRA, CHP, and KB has AI property and can be explored to develop them as AI agents.

Keywords: Unexplored plants, Kwath preparation, Anti-inflammatory activity.

(C) 2021 The Authors. Published by Innovare Academic Sciences Pvt Ltd. This is an open access article under the CC BY license (http://creativecommons.org/ licenses/by/4.0/) DOI: http://dx.doi.org/10.22159/ajpcr.2021v14i7.41735. Journal homepage: https://innovareacademics.in/journals/index.php/ajpcr

\section{SHORT COMMUNICATION}

The therapeutic practices in India at the household level are executed. However, few of them are evaluated with scientific assessment. Therefore, the community level experiences are mainly considered a piece of authentic information. Garg et al. have compiled the potential role of herbs located in Himalayan belt in various inflammatory disorders [1]. However, the validations for anti-inflammatory (AI) properties of most of the plants are now being updated. An inflammatory process is an event, which allows tissues to respond to injury or infection. Accordingly, the role of AI drugs is identified. Similarly, Shothaghna (AI) formulations in the traditional system are also defined [2]. Carrageenan-induced paw edema is a standard animal model for assessing the AI activity of several natural and synthetic compounds $[3,4]$. Many natural products, namely, Curcuma longa, Dasamoola, Terminalia chebula, and Boerhavia diffusa are validated as potential AI agents [5-8]. There are reports of adverse events with mild or moderate levels with chronic use of modern AI drugs such as NSAIDs [9]. In view of such limitations, the efforts are on to develop natural products as safe effective AI.

In the present study, we identified the areas, conducted personal interviews to document commonly used plants for medicinal, and food purposes by locals and compiled the best plants that are not validated experimentally. In view of this, a rationale was prepared to compile the information on various plants based on intensive literature surveys. We have shortlisted Cuscuta reflexa (CRA) and Cocculus hirsutus (CHP) from Himalayan belt and Southern region, respectively. The therapeutic potential of these plants is also mentioned in Ayurvedic text $[10,11]$. It was recorded sapera (snake charmer) community uses "amarbel" CRA as antidote for snake venom and its paste as an antiseptic and wound healing agent [12]. The other plant "sibbi teega" CHP is one of the green leafy vegetables from southern region described to be used by the population as it gives beneficial healthy effects. The community also reported its use in the treatment of blood dysentery; wounds skin disease, leukorrhea, and acute gonorrhea $[13,14]$. In addition, the mode of preparations by the local also prioritized to screen AI properties. These preparations are neglected or rarely been evaluated for the claims of local populations.

Both the plants were collected from respective regions. The plants were authenticated by Botanical Survey of India. The kwath of CRA (KCRA) and kwath of CHP (KCHP) were prepared by soaking $5 \mathrm{~g}$ of plant powder in $100 \mathrm{ml}$ water individually followed by evaporating the mixture to $50 \%$ at $100^{\circ} \mathrm{C}$. The filtrate was collected, lyophilized (Scanvac cool safe 110-4, Denmark), and stored at $-20^{\circ} \mathrm{C}$. The kwath blend (KB) of CRA and CHP was also prepared by mixing equal proportion of effective concentration of KCRA and KCHP. The AI property was assessed on Sprague Dawley rat $(n=60)$, male, 6-8 weeks old weighing 150-200 g, obtained from National Centre for Laboratory Animal Science, NIN, India. The Institutional Animal Ethics Committee (IAEC) approval (IAEC No. 54/IAEC/NIN/12/2016/BDK/SD rat) was obtained at animal facility ICMR-NIN. The rats were randomly divided into 10 groups, six in each. All the animals had given a sub-plantar injection of $100 \mathrm{ul}$ of the carrageenan- $\lambda$ dissolved in phosphate-buffered saline (PBS) (1\%) into the right hind paw except PBS in the negative control (NC) group. The various groups were as follows: Group I (NC), Group II positive control (PC), Group III (SD): Ibuprofen - $100 \mathrm{mg} / \mathrm{kg}$ ), Group IV (KCRA: $250 \mathrm{mg} / \mathrm{kg}$ b.w.), Group V (KCRA: $125 \mathrm{mg} / \mathrm{kg}$ b.w.), Group VI (KCRA: 62.5 mg/kg b.w.), Group VII (KCHP: 250 mg/kg b.w.), Group VIII (KCHP: $125 \mathrm{mg} / \mathrm{kg}$ b.w.), Group IX (KCHP: $62.5 \mathrm{mg} / \mathrm{kg}$ b.w.), and Group X (KB$500 \mathrm{mg} / \mathrm{kg} \mathrm{b.w)}$. The standard and test compounds have orally fed 
60 min before administering carrageenan in various concentrations with volume $10 \mathrm{ml} / \mathrm{kg}$ b.w. The edema was measured by digital Plethysmometer LE7500 (Panlab S.I.), at several time points, that is, before administration of carrageenan and $0,1,2,3,4,6,8,12$, and 24 after the injection of carrageenan. The percentage (\%) inhibition of edema was calculated using the formula

$\%$ inhibition $=$ To $-\mathrm{Tt} / \mathrm{T} 0 \times 100$

Where, Tt is the paw edema of test group at corresponding time and To is the paw edema of rats of PC group at the same time.

The statistical significance of the differences between various groups was determined by an ANOVA analysis for multiple comparisons by Prism version 5.0 (GraphPad Software, Inc., La Jolla, CA, USA). $\mathrm{p}<0.05$ was considered statistically significant. The ED50 values (the concentration that inhibits the paw volume response by $50 \%$ at particular time) were determined by plotting dose-response curves.

The anti-edematous property was evaluated with KCRA and KCHP in acute inflammation model in comparison with SD group (Fig. 1). This is a biphasic model, which commence with release of histamine, serotonin, and kinins after the injection of phlogistic agent between 0 and $1 \mathrm{~h}$. This is followed by the second phase of inflammation $\left(3^{\text {rd }} h\right)$ comprises the production of prostaglandins and various cytokines such as interleukin (IL)-1 $\beta$, IL-6, IL-10, and TNF- $\alpha$ [15]. The result demonstrated that the inflammation, which was initiated on administration of carrageenan, was highest and almost doubled in PC group at the $3^{\text {rd }} \mathrm{h}$. Both the plants (KCRA and KCHP) were effective during early phase at higher doses $(250 \mathrm{mg} / \mathrm{kg})$ compared to PC group $(\mathrm{p}<0.05)$. At the $1^{\text {st }} \mathrm{h}$, the activity recorded with KCRA was comparable with SD group. At the second phase $\left(3^{\text {rd }} \mathrm{h}\right)$, both the plants $(250 \mathrm{mg} / \mathrm{kg})$ inhibited edema significantly as compared to PC group. Although, both the plants were not comparable to SD group at $3 \mathrm{~h}$ (Table 1 ).

Based on ED50, both KCRA and KCHP were equally potent (EC50=139.8 and $147.3 \mathrm{mg} / \mathrm{kg}$, respectively) at the early phase (Fig. 2). However, the efficacy of KCRA was greater than KCHP at the second phase of inflammation (EC50=313.6 and $2760 \mathrm{mg} / \mathrm{kg}$, respectively). KCRA was efficacious and potent as an AI agent (Fig. 2). It indicates that KCRA might contain some AI agent responsible for the blockage of prostaglandins and inflammatory pathway. However, these AI responses were not superior to the SD group, which showed a percentage inhibition of $97.85 \%$ and $78.5 \%$, at the $1^{\text {st }}$ and $3^{\text {rd }} \mathrm{h}$, respectively. However, it was observed that the higher dose $(250 \mathrm{mg} / \mathrm{kg})$ of KCRA showed sustained inhibitory activity even after the $6^{\text {th }} \mathrm{h}$ unlike SD group $(\mathrm{p}<0.05)$. Our results are in accordance with Katiyar et al. The author has evaluated AI properties in a pre-clinical animal model and documented aqueous extract of CRA effective among all conventional extracts [16]. It is mostly observed in various scientific studies that combined formulations are much effective compared to single extracts [17]. Considering this, an effort was made to evaluate KB using both plants. Since KCHP was potent in the early phase and KCRA was efficacious in both phases, both the plants were used to prepare $\mathrm{KB}$ using equal proportion of KCRA and KCHP. The KB (500 mg/kg) significantly inhibited edema in comparison to PC group at all-time interval $(\mathrm{p}<0.05)$. The KB showed superior response compared to individual KCRA and KCHP, which could indicate that KCHP might be potentiating inhibitory action of KCRA (Table 1). The inhibitory activity was comparable with SD group at early hours. Unlike SD group, KB had effectively inhibited paw edema from $6^{\text {th }}$ hour (Fig. 1). Mallik and Nayak also investigated the effectiveness of CHP in combined formulation using Sesbania grandiflora flowers in the immunomodulatory model [18]. Oudhia has mentioned the therapeutic benefits of CHP in various diseases and reported that the property could be further enhanced when combined with various medicinal plants [19]. Our observation also demonstrated that when KCHP was given in combination with KCRA, the anti-inflammatory activity was superior.

The finding of the study has a relevance of having AI properties of KB and KCRA with described experience of reducing the risk of an inflammatory disorder. The paper has limitations, but the AI property assessed is on the standard in vivo experimental model.
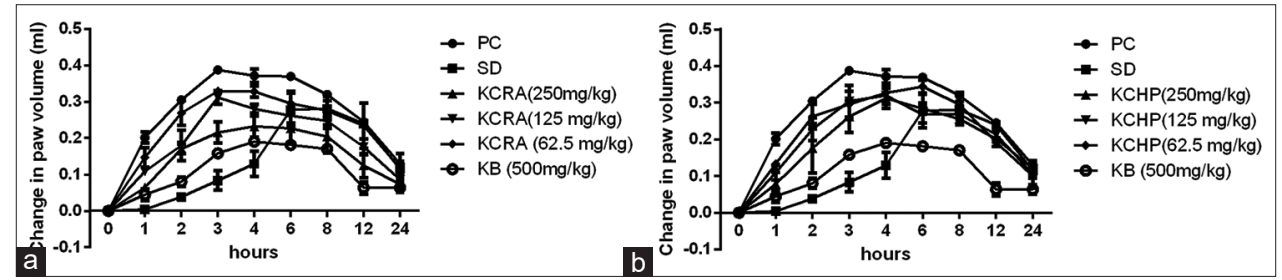

Fig. 1: The line diagram showing the effect of (a) kwath of Cuscuta reflexa (KCRA) and (b) kwath of Cocculus hirsutus (KCHP) at 62.5, 125, and $250 \mathrm{mg} / \mathrm{kg}$ b.w. on carrageenan-induced paw inflammation in Sprague Dawley rat at different time intervals (0-24 h). The effect of kwath blend of KCRA and KCHP (1:1 ratio; $500 \mathrm{mg} / \mathrm{kg}$ ) represented in both the graphs. Ibuprofen (100 mg/ $\mathrm{kg})$ was used as the standard anti-inflammatory drug. Values are mean \pm S.E.M $(n=6)$

Table 1: AI effect of KCRA and KCHP in carrageenan-induced paw edema model at the $1^{\text {st }}$ and $3^{\text {rd }} h$

\begin{tabular}{|c|c|c|c|c|}
\hline Groups & $1^{\text {st }} h(P V$ in $\mathrm{ml})$ & $\%$ inhibition of edema & $3^{\text {rd }} \mathrm{h}(\mathrm{PV}$ in $\mathrm{ml})$ & $\%$ inhibition of edema \\
\hline PC & $0.201 \pm 0.027^{\#}$ & - & $0.387 \pm 0.012^{\#}$ & - \\
\hline $\mathrm{SD}(100 \mathrm{mg} / \mathrm{kg})$ & $0.013 \pm 0.003^{*}$ & 97.85 & $0.083 \pm 0.046^{*}$ & 78.47 \\
\hline \multicolumn{5}{|l|}{ CRA } \\
\hline KCRA (250 mg/kg) & $0.064 \pm 0.017^{*}$ & 67.99 & $0.216 \pm 0.051^{* \#}$ & 44.36 \\
\hline KCRA (125 mg/kg) & $0.109 \pm 0.008^{* \#}$ & 45.94 & $0.312 \pm 0.033^{\#}$ & 19.38 \\
\hline KCRA (62.5 mg/kg) & $0.148 \pm 0.047$ \# & 26.70 & $0.329 \pm 0.017^{\#}$ & 15.07 \\
\hline \multicolumn{5}{|l|}{ CHP } \\
\hline KCHP (125 mg/kg) & $0.109 \pm 0.035^{* \#}$ & 45.77 & $0.304 \pm 0.075^{\#}$ & 21.36 \\
\hline KCHP (62.5 mg/kg) & $0.133 \pm 0.017 \#$ & 33.50 & $0.296 \pm 0.063^{\#}$ & 23.60 \\
\hline \multicolumn{5}{|l|}{ KB } \\
\hline $\mathrm{KB}(500 \mathrm{mg} / \mathrm{kg})$ & $0.036 \pm 0.027^{*}$ & 77.61 & $0.158 \pm 0.007^{* \#}$ & 59.17 \\
\hline
\end{tabular}

Mean \pm S.E.M (n=6); asterisks $(*)$ indicates significant difference ( $\mathrm{p} \leq 0.05)$ from positive control (PC). Hash mark (\#) indicates significant difference ( $\leq \leq 0.05)$ from SD group. AI: Anti-inflammatory, KCRA: Kwath of Cuscuta reflexa, KCHP: Kwath of Cocculus hirsutus, CRA: Cuscuta reflexa, CHP: Cocculus hirsutus, KB: Kwath blend, PV: Paw volume, SD: Standard drug 


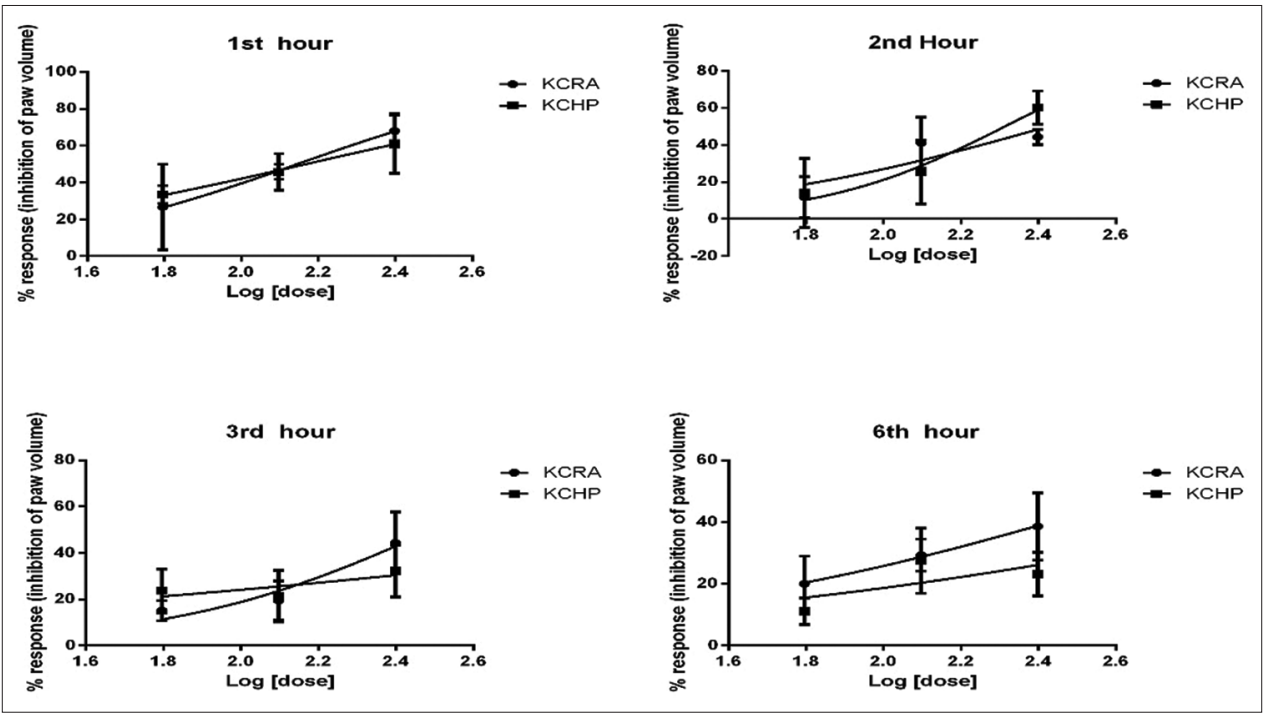

Fig. 2: The dose-response curves for ED50 calculations of kwath of Cuscuta reflexa and kwath of Cocculus hirsutus at various time points (1 ${ }^{\text {st }}$, $2^{\text {nd }}, 3^{\text {rd }}$, and $6^{\text {th }} h$ ) were depicted. X-axis represents doses in log. Y-axis represents percentage (\%) response (inhibition of paw volume)

\section{CONCLUSIONS}

The study demonstrates that KB and KCRA have potential AI property and can be ideal alternative to other inflammatory agents. This experiment further gives scope to study the mechanism of action for AI process.

\section{ACKNOWLEDGMENTS}

The technical support of Mr. Nagendra Babu, Project Assitant, is acknowledged. We acknowledge the fellowship support given by University Grant Commission (JRF no.1391/NET-DEC.2012). The authors are grateful to the Indian Council of Medical Research-NIN for extending the infrastructure and administrative support to undertake the work. We thank Dr. R Hemalatha (Director of the ICMR-NIN) for her constant encouragement.

\section{AUTHORS' CONTRIBUTIONS STATEMENT}

Anita Singh, SRF-UGC, has undertaken the investigation, planned, and executed experimental procedures followed by manuscript writing. Dr. Vandana Singh, MD (Ayurveda), has identified unexplored plants and supported experimental procedures and reference work. Dr. B. Dinesh Kumar, Supervisor, facilitated the design and planning experimental procedures apart from manuscript writing. All the authors have read and approved the final manuscript.

\section{DECLARATION OF COMPETING INTEREST}

The authors declare that there are no conflicts of interest.

\section{REFERENCES}

1. Garg S, Singh V, Ohri K. Healing herbs of world heritage site: The valley of flowers. Int J Appl Ayurved Res 2015;2:144-8.

2. Sastry SN. Charak Samhita of Agnivesh (Hindi Commentary, Reprint), Chikitsa Sthana, Swayathuchikitsa. Ch. 12. Varanasi: Chaukhambabharati Academy; 2006. p. 358-69.

3. Boominathan R, Parimaladevi B, Mandal S, Ghoshal S. Antiinflammatory evaluation of Ionidium suffruticosam Ging. in rats. J Ethnopharmacol 2004;91:367-70.

4. Panthong A, Norkaew P, Kanjanapothi D, Taesotikul T, Anantachoke N, Reutrakul V. Anti-inflammatory, analgesic and antipyretic activities of the extract of gamboge from Garcinia hanburyi Hook f. J Ethnopharmacol 2007;111:335-40.
5. Lee SY, Cho SS, Li Y, Bae CS, Park KM, Park DH. Anti-inflammatory effect of Curcuma longa and Allium hookeri co-treatment via NF-KB and COX-2 pathways. Sci Rep 2020;10:5718

6. Parekar RR, Bolegave SS, Marathe PA, Rege NN. Experimental evaluation of analgesic, anti-inflammatory and anti-platelet potential of Dashamoola. J Ayurveda Integr Med 2015;6:11-8

7. Bag A, Bhattacharyya SK, Pal NK, Chattopadhyay RR. Antiinflammatory, anti-lipid peroxidative, antioxidant and membrane stabilizing activities of hydroalcoholic extract of Terminalia chebula fruits. Pharm Biol 2013;51:1515-20.

8. Gharate M, Kasture V. Evaluation of anti-inflammatory, analgesic, antipyretic and antiulcer activity of Punarnavasava: An Ayurvedic formulation of Boerhavia diffusa. Orient Pharm Exp Med 2013;13:121-6.

9. Moore N, Pollack C, Butkerait P. Adverse drug reactions and drug-drug interactions with over-the-counter NSAIDs. Ther Clin Risk Manag 2015;11:1061-75

10. Tripathi I. Raj Nighantu with Dravyagunaprakashika Hindi Commentary. Varanasi: Choukhamba Krisnadas Academy; 2006.

11. Chunekar KC. In: Pandey GS, editor. Commentory, Bhavaprakash Nighantu (Indian Materia Medica) of Shri Bhavmishra (C.1500-1600 AD). Varanasi, India: Chowkamba Bharathi Academy; 2009.

12. Panghal M, Arya V, Yadav S, Kumar S, Yadav JP. Indigenous knowledge of medicinal plants used by Saperas community of Khetawas, Jhajjar district, Haryana, India. J Ethnobiol Ethnomed 2010;6:1-11.

13. Ashoka Trust for Research in Ecology and the Environment (ATREE), Convention on Biological Diversity, Karnataka Biodiversity Board; 2012.

14. Noureen S, Noreen S, Ghumman SA, Batool F, Bukhari SN. The genus Cuscuta (Convolvolaceac): An updated review on indigenous uses, phytochemistry, and pharmacology. Iran J Basic Med Sci 2019;22:1225-52.

15. Mansouri MT, Hemmati AA, Ghorbanzadeh B. A study of the mechanisms underlying the anti-inflammatory effect of ellagic acid in carrageenan-induced paw edema in rats. Indian $\mathrm{J}$ Pharmacol 2015;47:292-8.

16. Katiyar NS, Singh AP, Gangwar AK, Rao NV. Evaluation of carrageenan induced antiinflammatory activity of stem extracts of C. reflexa (Roxb) in rats. Int J Res Pharm Chem 2015;5:322-6.

17. Parasuraman S, Thing GS, Dhanaraj SA. Polyherbal formulation: Concept of ayurveda. Pharmacogn Rev 2014;8:73-80.

18. Mallik A and Nayak S. Study the immunomodulatory effects of combined extracts of Sesbania grandiflora flowers and Cocculus hirsutus leaves on the circulating antibody response. Am J Phytomed Clin Ther 2015;3:199-208.

19. Oudhia P. Research Documents with New Comments 2: Medicinal Herbs of Chhattisgarh, India Having Less Known Traditional Uses XXXV, Jaljamini (Cocculus hirsutus, family: Menispermaceae); 2010. 